\title{
РОЗДІЛ 8 СТАТИСТИКА
}

УдК 339.1-658.6

DOI: https://doi.org/10.32782/2304-0920/1-86-22

Марець О. Р.

Панчишин Т. В.

Прокопович-Павлюк I. В.

Львівський національний університет імені Івана Франка

\section{СУЧАСНІ БЗЗНЕС-МЕТРИКИ ОЦІНКИ ЕФЕКТИВНОСТІ МАРКЕТИНГОВИХ ЗАХОАІВ}

\begin{abstract}
У статті обгрунтовано необхідність застосування маркетингової аналітики під час планування маркетингових кампаній із залученням максимально можливої кількості каналів комунікації у часовому просторі. Напрямами дослідження є пошук ефективних бізнес-метрик, що використовуються для оцінки ефективності впровадження маркетингових заходів. Результати дослідження показали, що на сучасному етапі розвитку аналітичних можливостей традиційні методи підбору бізнес-метрик змінилися і стали більш залежними від сфери ведення бізнесу та конкурентного середовища, від каналів взаємодії з клієнтами та їхньої поведінки. Важливим при цьому є не лише набір універсальних метрик, а й специфічних, необхідних для окремих маркетингових каналів просування продукції. Застосування розглянутих у статті бізнес-метрик дасть змогу оперативніше оцінювати ефективність бізнес-процесів на кожному етапі маркетингової кампанії.

Ключові слова: бізнес-метрики, маркетингова аналітика, залучення клієнтів, утримання клієнтів, жит-
\end{abstract} тєва цінність клієнта, управління відносинами з клієнтами, коефіцієнт конверсії.

Постановка проблеми. Швидкий розвиток інформаційних технологій дає підприємцям можливість приймати стратегічні рішення щодо впровадження нових товарів та вдосконалення існуючих на основі аналізу великих масивів даних. Інструментами для здійснення такого аналізу володіє маркетингова аналітика. Отже, актуальним стає питання вибору коректних показників та методів для вирішення практичних завдань бізнесу: вимірювання ефективності роботи з (потенційними) покупцями, визначення проблемних ділянок бізнесу та для пошуку шляхів удосконалення. Для цього в маркетинговій аналітиці використовують бізнес-метрики. Метою статті $€$ узагальнення існуючих підходів побудови системи бізнес-метрик маркетингової аналітики, пошук проблем та перспектив показників оцінки ефективності маркетингової діяльності компаній.

Аналіз останніх досліджень і публікацій. Різні аспекти функціонування Інтернет-маркетингу досліджено у працях таких авторів, як: С.Г. Антощук, О.О. Фоміна, Ю.О. Пуніна, А.В. Федорченко, Є.О. Голишева, Т.В. Кириченко, Я.А. Коваленко, Н.С. Ілляшенко, О.С. Савченко, О.М. Сохацька, О.А. Легкий, С.Є. Хрупович. Праці зазначених авторів містять теоретичні аспекти вивчення понять та категорій маркетингової політики.

Виділення не вирішених раніше частин загальної проблеми. Модель формування бізнес-метрики ефективності маркетингових заходів залежить від сфери бізнесу, конкурентного середовища, каналів взаємодії із споживачем, його поведінки та багатьох інших чинників. Ураховуючи сучасні можливості маркетингових досліджень, що базуються на аналітиці значних масивів даних, одним із завдань є обгрунтування ключових метрик бізнес-процесів та маркетингових заходів, що визначатимуть стратегію розвитку фірми та подальші управлінські рішення.

Мета статті. Володіючи прийомами системного підходу до аналізу даних, що впливають на марке- тингову діяльність, можна домогтися вирішення проблеми та надавати рекомендації для подальших дій. Саме тому системний підхід до аналізу маркетингової діяльності підприємства визначає вибір та обгрунтування системи метрик, які дають змогу оцінювати нинішній стан прав.

Виклад основного матеріалу. Маркетингова аналітика - це практика вимірювання та аналізу маркетингової діяльності підприємства для підвищення її ефективності та оптимізації витрат [11].

Умовно можна виділити два завдання маркетингової аналітики: збір даних і їх інтерпретація. Інформацію збирають із різних джерел: які кнопки натискають користувачі, як часто використовують продукт, які функції продукту популярні, а які ні. Ці дані дають відповідь на питання, що саме відбувається, але не пояснюють причин. На другому етапі аналітик за допомогою математичних методів та моделей інтерпретує цифри фактами, які пояснюють поведінку користувачів.

Приклади завдань, які допомагає вирішувати маркетингова аналітика [1, с. 96]: вимірювати та поліпшувати результати Інтернет-маркетингових кампаній; персоналізувати кампанії для досягнення кращої продуктивності; оптимізувати комунікації у соціальних мережах; допомогти у розробленні вмісту, який $€$ релевантним для користувача; поліпшити обслуговування клієнтів; підвищити рівень задоволеності клієнтів; посилити лояльність клієнтів; передбачити певні дії користувачів; допомагати приймати більш точні та своєчасні рішення.

Для вирішення кожного із цих завдань у маркетинговій аналітиці використовують бізнес-метрики.

Бізнес-метрика - це показник для вимірювання ефективності бізнес-процесу на кожному його етапі, а також для розрахунку показників витрат та прибутку [9; 11]. У табл. 1 подано систему бізнес-метрик маркетингової аналітики 3 погляду маркетингових каналів. 
Бізнес-метрики маркетингової аналітики з погляду маркетингових каналів

\begin{tabular}{|c|c|c|c|}
\hline $\begin{array}{c}\text { Маркетинговий } \\
\text { канал }\end{array}$ & Метрика & $\begin{array}{c}\text { Маркетинговий } \\
\text { канал }\end{array}$ & Метрика \\
\hline \multirow[b]{2}{*}{ Вебсайт } & \multirow{2}{*}{$\begin{array}{l}\text { - Загальна кількість візитів } \\
\text { - Кількість унікальних візитів } \\
\text { - Перегляди сторінки } \\
\text { - Коефіцієнт утримання } \\
\text { - Коефіцієнт конверсії } \\
\text { - Середня тривалість сесії } \\
\text { - Час, проведений на сторінці } \\
\text { - Перегляди сторінки за сесію } \\
\text { - Показник відмов } \\
\text { - Швидкість виходу } \\
\text { - Кількість } \\
\text { - Коефіцієнт утрачених клієнтів }\end{array}$} & $\begin{array}{l}\text { Оптимізація } \\
\text { пошукових } \\
\text { систем }\end{array}$ & $\begin{array}{l}\text { - Рейтинг ключових слів } \\
\text { - Унікальні домени } \\
\text { - Авторитет домену } \\
\text { - Джерела трафіку } \\
\text { - Швидкість сторінки } \\
\end{array}$ \\
\hline & & \multirow[t]{2}{*}{$\begin{array}{l}\text { Маркетингові } \\
\text { події }\end{array}$} & $\begin{array}{l}\text { - Кількість зареєстрованих учасників } \\
\text { - Відвідуваність події } \\
\text { - Згадки у соціальних мережах } \\
\text { - Опитування задоволеності } \\
\text { - Чистий бал промоутера (Net promoter } \\
\text { score, NPS) }\end{array}$ \\
\hline \multirow{2}{*}{$\begin{array}{l}\text { Електронна } \\
\text { пошта }\end{array}$} & \multirow{2}{*}{$\begin{array}{l}\text { - Відсоток відкритих листів } \\
\text { - Відсоток листів, які не досягли } \\
\text { адресатів } \\
\text { - Частка натискань на (CTR, } \\
\text { click-through rate) електронні листи } \\
\text { - Відсоток підписок } \\
\text { - Окупність інвестицій (ROI) } \\
\text { - Нові підписники }\end{array}$} & & $\begin{array}{l}\text { - Валовий дохід } \\
\text { - Дохід за промо-кодом } \\
\text { - Кількість потенційних клієнтів } \\
\text { - Кількість клієнти, які придбали }\end{array}$ \\
\hline & & \multirow[b]{2}{*}{ Соціальні медіа } & \multirow{2}{*}{$\begin{array}{l}\text { - Залученість } \\
\text { - Охоплення } \\
\text { (органічне, платне, вірусне) } \\
\text { - Кількість згадок } \\
\text { - Кількість нових підписників } \\
\text { - Коефіцієнт зростання кількості } \\
\text { підписників } \\
\text { - Трафік }\end{array}$} \\
\hline Платна реклама & $\begin{array}{l}\text { - Частка натискань (CTR) } \\
\text { - Вартість натискання } \\
\text { - Вартість потенційного клієнта } \\
\text { - Кількість потенційних клієнтів (MQL, } \\
\text { - Marketing qualified leads) }\end{array}$ & & \\
\hline
\end{tabular}

Джерело: опрацьовано авторами на основі $[6 ; 9 ; 11]$

Під час вибору коректних метрик слід ураховувати, про яке джерело інформації йдеться, хто буде використовувати ці дані, робити висновки і приймати бізнес-рішення. Наприклад, керівникам достатньо бачити огляд кожного маркетингового каналу, а завдання аналітиків - заглибитися у показники для глибшого розуміння повсякденної діяльності задля її оптимізації.

У 2007 р. інвестор Дейв МакКлюр розробив і запропонував метод AARRR - систему метрик для оцінки бізнес-процесів. Уживають також іншу назву методу - «піратські метрики» через особливість вимови абревіатури AARRR [8].

Послідовність вибору метрик за цим підходом відповідає традиційній лінійці конверсій: залучення (acquisition), активація (activation), утри- мання (retention), рекомендації (referral), дохід/ монетизація (revenue) (рис. 1).

Залучення - це перш за все донесення інформації про товари чи послуги до потенційних користувачів. Для оцінки ефективності на цьому етапі використовують показники конверсії кожного каналу комунікації. Частка відмов (Bounce rate) також є важливою метрикою для цільових каналів залучення. Усі ці метрики допомагають бізнесу виміряти якість свого трафіку та загальну поведінку користувачів.

На етапі активацї залучають клієнтів, які вже знайомі 3 товаром/послугою. Він пов'язаний із так званою Ага! реакцією - моментом, коли клієнт усвідомлює цінність товару/послуги і вирішує стати постійним покупцем. Метрики, які відслід-

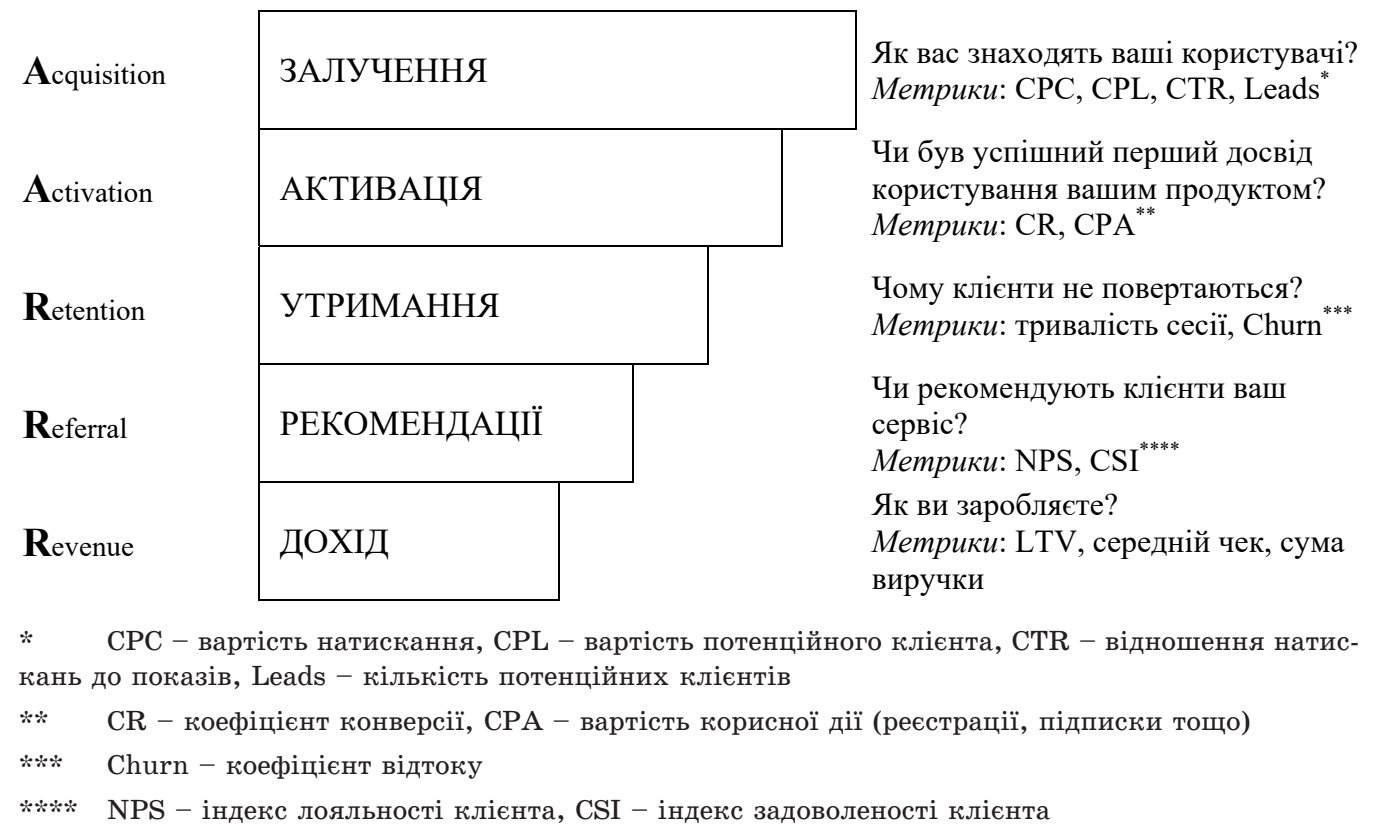

Рис. 1. Модель AARRR для побудови системи метрик компанії

Джерело: побудовано авторами на основі даних [8] 
ковують на цьому етапі, - це час перебування на сайті, кількість натискань і переглянутих сторінок.

На етапі утрилання маркетологи спрямовують свої зусилля на вже існуючих клієнтів, щоб вони робили повторні замовлення. Тут важливою є точність таргетування. 3 іншого боку, завданням бізнесу на цьому етапі є уникнення відтоку клієнтів. Для цього важливо зрозуміти причини, чому клієнти перестають користуватися продуктом.

Важливо зробити так, щоб користувачі сервісу рекомендували його іншим потенційним користувачам. Щоб виміряти результати на цьому етапі, клієнтам пропонують пройти опитування та визначають індекси лояльності та задоволеності клієнтів.

Цільові метрики на етапі отримання доходу це ROI, сукупний дохід від користувача (LTV), середня виручка на одного користувача (ARPU).

Метод AARRR містить усі ключові етапи зростання, і він популярний завдяки своїй простоті. Проте нині цей підхід критикують, оскільки для більшості сервісів високий рівень залучення нових користувачів не обов'язково означає успішний стан справ. Так, кількість мобільних додатків у App Store у 2020 р. порівняно з 2008 р. збільшилася у 69 разів [12]. Однак уже за перші три дні після встановлення додатки втрачають у середньому 77\% своїх щоденних активних користувачів (DAU). За 30 днів вони втрачають 90\% DAU, за 90 днів - понад 95\%. Тож якщо середньостатистичний додаток залучає 100 нових користувачів, через три місяці його активна аудиторія становить лише п'ять осіб [7]. Таким чином, на перший план виходить утримання наявних клієнтів, і актуальною зараз стає модель RARRA, яку запропонували у 2017 р. [13] (рис. 2).

Відповідно до цього змінюється пріоритетність метрик, за якими необхідно спостерігати для досягнення успіху.

Вибір метрик для оцінки ефективності бізнесу залежить від специфіки діяльності, тривалості діяльності підприємства, користувачів та інших чинників. Проте є набір універсальних метрик, які можна застосувати для більшості випадків.

Основними бізнес-метриками є [2]:

- CAC (customer acquisition cost) - вартість залучення одного споживача;

- LTV (lifetime value) - прибуток, який приносить споживач протягом усього періоду його користування продуктом або послугою компанії;
- ARPU (average revenue per user) - середній щомісячний дохід у розрахунку на одного споживача;

- CR (conversion rate) - частка користувачів, які здійснили цільову дію (коефіцієнт конверсій).

Вартість залучення одного споживача (CAC) це сума, яку компанія витрачає на маркетингові та рекламні заходи, щоб залучити клієнтів. Перед тим як потенційний споживач стане клієнтом сервісу, 3 ним асоціюється сума витрат, яка дорівнює САC. Таким чином, спочатку компанія має витрати, пов'язані з новим клієнтом. Коли від нього надходять оплати, компанія перш ніж заробити, виходить у нуль. Цей процес називають поверненням вартості залучення споживача (CAC Payback) часом, необхідним для того, щоб окупити CAC [2].

Аналіз показника вартості залучення клієнmiв (CAC) допомагає побудувати модель просування продукту, стежити за ефективністю каналів, поліпшувати стратегію їх використання i намагатися оптимізувати витрати без утрати клієнтів. Це дуже важливо і безпосередньо впливає на долю бізнесу і дохід бізнес-проєкту.

Розрахувати САC можна двома способами: простим, щоб просто побачити загальну картину стану бізнесу, та складним, більш точним.

У першому випадку САС - це відношення суми всіх витрат на рекламу для залучення нових клієнтів до кількості нових клієнтів, які прийшли в результаті рекламних дій. Для більшої точності результату в чисельник формули треба включати всі складники витрат на рекламні дії: зарплати фахівцям із реклами, вартість фото та відео для рекламних постів, роботу дизайнера, оплату робіт із написання рекламних текстів, витрати на зв'язок тощо. Це складніший, більш точний спосіб розрахунку CAC.

Показник вартості залучення клієнтів аналізують разом із показникол життєвої иінності клієнта (Lifetime Value). ЖЖиттєва цінність клієнта це дохід, який очікують отримати з конкретного клієнта за час його активної взаємодії з бізнесом [9, с. 24]. LTV пов'язаний із поняттям CLT (Customer Lifetime) - середнім часом залучення споживача в послуги або продукти компанії.

Цей показник дуже важливий для оцінки маркетингових та рекламних дій, оскільки:

- він є складником розрахунку ROI (повернення інвестицій). ROI - це один зі способів оцінити віддачу від витрат на рекламу;

\begin{tabular}{|c|c|c|}
\hline Retention & УТРИМАННЯ & $\begin{array}{l}\text { Зробіть так, щоб ваші користувачі } \\
\text { поверталися }\end{array}$ \\
\hline Activation & АКТИВАЦІЯ & $\begin{array}{l}\text { Нові користувачі повинні побачити } \\
\text { цінність вашого сервісу відразу }\end{array}$ \\
\hline Referral & РЕКОМЕНДАЦІЇ & $\begin{array}{l}\text { Зробіть так, щоб ваші користувачі } \\
\text { рекомендували ваш сервіс }\end{array}$ \\
\hline Revenue & ДОХІД & Заробляєте в результаті цих дій \\
\hline Acquisition & ЗАЛУЧЕННЯ & $\begin{array}{l}\text { Використовуйте свою аудиторію, } \\
\text { щоб залучити ще більше } \\
\text { користувачів }\end{array}$ \\
\hline
\end{tabular}

Рис. 2. Модель RARRA для побудови системи метрик компанії 
- допомагає визначити цільову аудиторію бізнесу i, таким чином, збільшити ефективність рекламних дій та оптимізувати стратегію утримання клієнтів;

- дає змогу поділити клієнтів на групи з погляду вигідності для бізнесу.

Високе значення LTV указує на те, що користувачі задоволені сервісом і продуктом та повертаються, щоб зробити повторну покупку. Низький LTV означає протилежне.

Співвідношення LTV та CAC дає змогу оцінити успішність маркетингової стратегії. Якщо це відношення менше 1, це означає, що бізнес збитковий; якщо дорівнює 1 - кошти з кожного клієнта втрачаються; якщо більше 3 - ефективність бізнес-моделі є на еталонному рівні [4, с. 24].

Найпоширеніші дії для зменшення вартості залучення одного споживача включають [4, с. 24]: оптимізацію конверсії; підвищення користувацької цінності за рахунок додаткових модифікацій товару; запровадження системи управління відносинами 3 клієнтами CRM (customer relationship management).

Середній дохід від одного клієнта (ARPU) містить інформацію для вимірювання цінності продукту, прогнозування прибутку і дає змогу приймати обгрунтовані рішення щодо бізнесу [5]. Ця метрика показує, скільки користувач витрачає на продукти компанії у розрахунку на місяць та є основою для поділу клієнтів на групи з погляду їх корисності для бізнесу за минулий місяць. Таким чином, якщо аналітик визначить, які клієнти є найбільш платоспроможними, можна підвищити середню виручку за місяць.

Показники LTV та APRU пов'язані між собою, проте їх часто плутають.

LTV - це прибуток, який приносить клієнт протягом роботи з ним. ARPU показуе прибуток від роботи з користувачем за певний період. Різниця між цими метриками - Lifetime - тривалість життя клієнта в рамках бізнес-проекту [3].

ARPU не має оптимального значення. Але $е$ одне правило: якщо ARPU знижується, необхідно залучати більше клієнтів. Цю метрику не можна конкретно оцінити, тому що вона дуже сильно пов'язана з кількістю клієнтів.

Коеріиієнт конверсій (CR) - частка користувачів, які здійснили цільову дію. Це один з основних показників ефективності в Інтернет-маркетингу. Показник конверсії, як і будь-яка інша метрика в Інтернет-маркетингу, не є абсолютною величиною. На величину конверсії впливають різні чинники: тематика ніші, середній чек, рівень конкуренції, асортимент товарів.

Експерти вивели середній коефіцієнт конверсії в найпопулярніших нішах, значення якого можна дотримуватися під час розроблення бізнес-плану стартапу. Залежно від сфери його значення коливається від $2 \%$ до $10 \%$ [3].

Висновки і пропозиції. Маркетингова аналітика - це набір інструментів, що дає змогу оцінювати ефективність маркетингових дій та надає важливу інформацію для оптимізації продуктивності, діагностики проблем у роботі з клієнтами та співвіднесення діяльності клієнта з його довгостроковою цінністю.

Запропонована у 2007 р. система моніторингу метрик AARRR, що відповідає традиційній лійці конверсій: залучення (acquisition), активація (activation), утримання (retention), дохід (revenue), рекомендації (referral), нині є менш актуальною. Унаслідок зростання конкурентної боротьби за клієнта зросла вартість залучення нових клієнтів, та ефективніше працюватиме бізнес, який зосереджується на утриманні наявних клієнтів. Таким чином, нині більш актуальною є система побудови метрик за принципом RARRA (retention, activation, referral, revenue, acquisition), де залучення нових клієнтів знаходиться на останньому місці. Для ефективнішого управління маркетинговою діяльність доцільно використовувати такі бізнес-метрики: вартість залучення одного споживача (CAC, customer acquisition cost), вартість споживача протягом усього його життя як споживача продуктів або послуг компанії (LTV, lifetime value), середній щомісячний дохід у розрахунку на одного споживача (ARPU, average revenue per user) та частка користувачів, які здійснили цільову дію (CR, conversion rate).

Список використаних джерел:

1. Антощук С.Г., Фомін О.О. Модель маркетингу, яка керується даними. Маркетинг $i$ иифрові технологї. 2017. V. 1. № 2. P. 92-101. URL: http://mdt-opu.com.ua/index.php/mdt/article/view/18 (дата звернення: 23.03.2021).

2. Бізнес-метрики: як рахувати ключові показники і що з ними робити. Будуй своє : вебсайт. URL: https://buduysvoe.com/ publications/biznes-metryky-yak-rahuvaty-klyuchovi-pokaznyky-i-shcho-z-nymy-robyty (дата звернення: 23.03.2021).

3. Основні метрики і KPI в Інтернет-маркетингу. Idea digital agency : вебсайт. URL: https://ideadigital.agency/osnovnimetriki-i-kpi-v-internet-marketingu/ (дата звернення: 13.03.2021).

4. Сохацька О.М., Легкий О.А. Ефективність цифрових маркетингових комунікацій: від постановки мети до оцінювання результату. Маркетинг і иифрові технологіï. URL: https://mdt-opu.com.ua/index.php/mdt/article/view/13 (дата звернення: 13.03 .2021$)$.

5. Шпак C. Показник ARPU: як порахувати, зробити висновки і поліпшити. Carrot Blog : вебсайт. URL: https://www.carrotquest.io/blog/arpu/ (дата звернення: 18.03.2021).

6. Alscher D. 43 Marketing Metrics to Show Your Boss You're Killing It. URL: https://learn.g2.com/marketing-metrics\#g (дата звернення: 13.03.2021).

7. Bonnie E. AARRR vs. RARRA: Which is Better? URL: https://clevertap.com/blog/aarrr-metrics-vs-rarra-framework/ (дата звернення: 18.03.2021).

8. Damasio H. AARRR Pirate Metrics \& The Growth Hacking Mindset. URL: https://thewayofdamasio.com/aarrr-piratemetrics-and-the-growth-hacking-mindset/ (дата звернення: 22.03.2021).

9. Key marketing metrics every marketer should measure. URL: https:/www.klipfolio.com/resources/kpi-examples/ marketing (дата звернення: 22.03.2021).

10. Marketing Analytics - Success Through Analysis. URL: https://www.wordstream.com/marketing-analytics (дата звернення: 22.03.2021).

11. Marketing Metrics: A Complete Guide to the Most Common Marketing Metrics and Marketing Analytics. URL: https://www.freemarketingmetrics.com/marketing-metric-topics/what-are-marketing-analytics-and-marketing-metrics9e3ak (дата звернення: 22.03.2021).

12. Number of available apps in the Apple App Store from 2008 to 2020. URL: https://www.statista.com/statistics/268251/ number-of-apps-in-the-itunes-app-store-since-2008/ (дата звернення: 13.03.2021).

13. Papp G. Why Focusing Too Much on Acquisition Will Kill Your Mobile Startup. URL: https://phiture.com/mobilegrowthstack/ why-focusing-on-acquistion-will-kill-your-mobile-startup-e8b5fbd81724/ (дата звернення: 13.03.2021). 


\title{
References:
}

1. Antoshhuk S.Gh., Fomin O.O. (2017) Modelj marketynghu, jaka kerujetjsja danymy [A data-driven marketing model] Marketyngh i cyfrovi tekhnologhiji, [Marketing and digital technologies], vol. 1, no. 2, pp. 92-101. Available at: http://mdt-opu.com.ua/index.php/mdt/article/view/18 (accessed 23 March 2021).

2. Biznes-metryky: jak rakhuvaty kljuchovi pokaznyky i shho z nymy robyty. Buduj svoje: website. Available at: https://buduysvoe.com/publications/biznes-metryky-yak-rahuvaty-klyuchovi-pokaznyky-i-shcho-z-nymy-robyty (accessed 23 March 2021).

3. Osnovni metryky i KPI v internet-marketynghu. Idea digital agency: website. Available at: https://ideadigital.agency/ osnovni-metriki-i-kpi-v-internet-marketingu/ (accessed 23 March 2021).

4. Sokhacjka O.M., Leghkyj O.A. (2017) Efektyvnistj cyfrovykh marketynghovykh komunikacij: vid postanovky mety do ocinjuvannja rezuljtatu [The effectiveness of digital marketing communications: from goal setting to performance evaluation]. Marketyngh i cyfrovi tekhnologhiji [Marketing and digital technologies], vol. 1, no. 2, pp. 4-31. Available at: https://mdt-opu.com.ua/index.php/mdt/article/view/13 (accessed 13 March 2021).

5. Shpak S. Pokaznyk ARPU: jak porakhuvaty, zrobyty vysnovky i polipshyty. Carrot Blog: website. Available at: https://www.carrotquest.io/blog/arpu/ (accessed 18 March 2021).

6. Alscher D. 43 Marketing Metrics to Show Your Boss You're Killing It. Available at: https://learn.g2.com/marketingmetrics\#g (accessed 13 March 2021).

7. Bonnie E. AARRR vs. RARRA: Which is Better? Available at: https://clevertap.com/blog/aarrr-metrics-vs-rarra-framework/ (accessed 13 March 2021).

8. Damasio H. AARRR Pirate Metrics \& The Growth Hacking Mindset. Available at: https://thewayofdamasio.com/aarrrpirate-metrics-and-the-growth-hacking-mindset/ (accessed 22 March 2021).

9. Key marketing metrics every marketer should measure. Available at: https://www.klipfolio.com/resources/kpi-examples/ marketing (accessed 22 March 2021).

10. Marketing Analytics - Success Through Analysis. Available at: https://www.wordstream.com/marketing-analytics (accessed 22 March 2021).

11. Marketing Metrics: A Complete Guide to the Most Common Marketing Metrics and Marketing Analytics. Available at: https://www.freemarketingmetrics.com/marketing-metric-topics/what-are-marketing-analytics-and-marketing-metrics9e3ak (accessed 22 March 2021)

12. Number of available apps in the Apple App Store from 2008 to 2020. Available at: https://www.statista.com/statistics/268251/number-of-apps-in-the-itunes-app-store-since-2008/ (accessed 13 March 2021)

13. Papp G. Why Focusing Too Much on Acquisition Will Kill Your Mobile Startup. Available at: https://phiture.com/mobilegrowthstack/why-focusing-on-acquistion-will-kill-your-mobile-startup-e8b5fbd81724/ (accessed 13 March 2021).

Марець О. Р.

Панчишин Т. В.

Прокопович-Павлюк И. В.

Львовский национальный университет имени Ивана Франко

\section{СОВРЕМЕННЫЕ БИЗНЕС-МЕТРИКИ ОЦЕНКИ ЭФФЕКТИВНОСТИ МАРКЕТИНГОВЫХ МЕРОПРИЯТИЙ}

\section{Резюме}

В статье обоснована необходимость применения маркетинговой аналитики, которая учитывает максимально возможное число каналов коммуникации во временном измерении. Для оценки эффективности выполнения маркетинговых мероприятий в маркетинговой аналитике используют бизнес-метрики. Результаты проведенного исследования показали, что на современном этапе развития аналитических возможностей традиционные методы подбора бизнес-метрик меняются и зависят от сферы ведения бизнеса и конкурентной среды, от каналов взаимодействия с клиентами и их поведения. При этом весомую роль играют не только универсальные метрики, но и специфические метрики, используемые для оценки отдельных маркетинговых каналов продвижения продукции. Применение рассмотренных в статье бизнес-метрик позволит более оперативно оценивать эффективность бизнес-процессов на каждом этапе рекламной кампании.

Ключевые слова: бизнес-метрики, маркетинговая аналитика, привлечение клиентов, удержание клиентов, жизненная ценность клиента, управление отношениями с клиентами, коэффициент конверсии.

\author{
Marets Oksana \\ Panchyshyn Taras \\ Prokopovych-Pavlyuk Iryna \\ Ivan Franko National University of Lviv
}

\section{MODERN BUSINESS METRICS FOR EVALUATION OF EFFICIENCY OF MARKETING MEASURES}

\section{Summary}

The article substantiates the need to use marketing analytics when planning marketing campaigns with the involvement of the maximum possible number of communication channels in a time dimension. The area of research is the search for effective business metrics used to assess the effectiveness of the implementation of marketing activities. The results of the study showed that at the present stage of development of analytical capabilities, traditional methods of selecting business metrics are changing and depend on the scope of business and the competitive environment, the channels of interaction with customers and their behavior. When choosing the correct metrics, analyst should take into account all the sources of the information, also who will use this data to draw conclusions and make business decisions. Thus, to analyze the performance of the website, we should determine the number of visits, conversion and retention rates. We can evaluate effectiveness of email campaigns by the proportion of open emails, the number of clicks, and return on investment. In the case of paid advertising analysts should estimate the quantity and cost of clicks, the number and value 
of potential customers. For effective management of marketing activities, it is advisable to use the following business metrics: the cost of attracting one consumer, the cost of the consumer throughout his/her life as a consumer of the company's products or services, the average monthly income per consumer and the proportion of users who performed the targeted action. The primary indicators for calculating business metrics are the company's revenue and expenses. To obtain a reliable value for a business metric, one should take into account all types of expenses associated with product promotion - salaries for specialists in advertising, the cost of photos and videos for advertising posts, designer's work, payment for writing advertising texts, communication costs, and others. The sequence of metric selection according to one approach corresponds to the traditional conversion funnel. However, nowadays for the most services a high level of new user engagement does not necessarily mean success. Thus, better sequence of metrics is as follows: retention, activation, referral, revenue, acquisition.

Keywords: business metrics, marketing analytics, customer engagement, customer retention, customer value, customer relationship management, conversion rate. 